\title{
Identification of Cryptosporidium species and genotypes in dairy cattle in Brazil
}

\author{
Identificação de espécies e genótipos de Cryptosporidium em bovinos leiteiros no Brasil \\ Flavio Medeiros Paz e Silva ${ }^{1,2 *}$; Raimundo Souza Lopes ${ }^{1}$; João Pessoa Araújo-Junior ${ }^{2}$
}

\begin{abstract}
${ }^{1}$ Laboratório de Enfermidades Parasitárias, Departamento de Clínica Veterinária, Faculdade de Medicina Veterinária e Zootecnia, Universidade Estadual Paulista - UNESP, Botucatu, SP, Brasil

${ }^{2}$ Laboratório de Diagnóstico Molecular, Departamento de Microbiologia-Imunologia, Instituto de Biociências, Universidade Estadual Paulista - UNESP, Botucatu, SP, Brasil
\end{abstract}

Received February 9, 2012

Accepted May 3, 2012

\begin{abstract}
In this study, we identified Cryptosporidium species and genotypes present in dairy cattle in the central region of São Paulo state, Brazil. Fecal specimens were collected from 200 animals (100 calves and 100 cows) in ten dairy farms. Fecal samples were examined using microscopic examination (ME), enzyme immunoassay (EIA) and polymerase chain reaction (PCR). Cryptosporidium species and genotypes were determined by restriction fragment length polymorphism (RFLP) or DNA sequencing analysis of the SSU-rRNA and GP60 genes. The occurrence of Cryptosporidium spp. infection was $14 \%(28 / 200)$. The occurrence in calves (26\%) was significantly higher than in cows $(2 \%)$. Of the 27 Cryptosporidium-positive specimens submitted to genotyping, C. andersoni was identified in 23 (85.1\%), C. bovis in three $(11.1 \%)$, and the zoonotic $C$. parvum subtype IIaA15G2R1 in one $(3.7 \%)$. The study demonstrates that Cryptosporidium spp. infection was common and widespread in dairy cattle in this region and that calves have a high prevalence of $C$. andersoni. Furthermore, the presence of $C$. parvum subtype IIaA15G2R1 indicates that dairy calves from this region should be considered a potential source of zoonotic Cryptosporidium oocysts.
\end{abstract}

Keywords: Cryptosporidium spp., cattle, PCR-RFLP, sequencing, genotyping.

\section{Resumo}

No presente estudo foram identificadas espécies e genótipos de Cryptosporidium originadas de bovinos leiteiros na região central do estado de São Paulo, Brasil. Amostras fecais foram coletadas de 200 animais (100 bezerros e 100 vacas) em 10 propriedades leiteiras. As amostras foram examinadas utilizando os métodos de microscopia óptica (MO), ensaio imunoenzimático (EI) e reação em cadeia da polimerase (PCR). As espécies e genótipos de Cryptosporidium foram determinados pelo método de polimorfismo no tamanho dos fragmentos de restrição (RFLP) ou sequenciamento dos genes SSU-rRNA e GP60. A infecção por Cryptosporidium spp. teve ocorrência de 14\% (28/200). A ocorrência em bezerros $(26 \%)$ foi significativamente maior do que em vacas (2\%). Do total de 27 amostras positivas submetidas à caracterização genética, $C$. andersoni foi identificado em 23 (85.1\%), C. bovis em três (11.1\%) e C. parvum subtipo IIaA15G2R1 em uma (3.7\%). O presente estudo demonstrou que a infecção por Cyptosporidium é comum e difundida em bovinos leiteiros nessa região e que bezerros possuem uma alta prevalência de $C$. andersoni. A presença de $C$. parvum subtipo IIaA15G2R1 indica que bezerros leiteiros dessa regiáo devem ser considerados uma fonte de oocistos de Cryptosporidium com potencial zoonótico.

Palavras-chave: Cryptosporidium spp., bovinos, PCR-RFLP, sequenciamento, genotipagem.

\section{Introduction}

Cryptosporidium is an apicomplexan parasite that infects the microvillus border of the gastrointestinal epithelium of a wide range of vertebrate hosts, including humans and cattle. In farm animals,

\section{* Corresponding author: Flávio Medeiros Paz e Silva}

Departamento de Microbiologia-Imunologia, Instituto de Biociências,

Universidade Estadual Paulista- UNESP, Distrito de Rubiáo Júnior,

s/n, CEP 18618-970, Botucatu, SP, Brasil

e-mail: flaviopaz@hotmail.com
Cryptosporidium infection causes disorders of the digestive system and is a common cause of morbidity in neonatal calves (OLSON et al., 2004). Cryptosporidium spp. has been found in beef and dairy cattle worldwide (HAMNES et al., 2006; GEURDEN et al., 2007; THOMPSON et al., 2007). Longitudinal studies have found high prevalence rates in young calves in some herds, with infections levels frequently reaching $100 \%$ (SANTÍN et al., 2008). Cattle have been reported as the primary host for four species of 
Cryptosporidium with significant biological differences: C. parvum, C. bovis, C. ryanae (previously identified as the Cryptosporidium deer-like genotype) and $C$. andersoni (SANTÍN et al., 2004; FAYER et al., 2005, 2006, 2008). Recent studies have reported that susceptibility of cattle to Cryptosporidium spp. varies with host age (SANTÍN et al., 2004; MENDONÇA et al., 2007; BROGLIA et al., 2008). The species $C$. parvum infects the intestine of neonatal and pre-weaned calves (0-2 months old) and shows high infection rates in dairy herds (COKLIN et al., 2007; SANTÍN et al., 2008). Infections with $C$. bovis are common among post-weaned dairy calves (2-11 months-old) in many geographical regions (SANTÍN et al., 2004; FENG et al., 2007; FELTUS et al., 2008). C. ryanae has been found in pre-weaned and post weaned calves (FENG et al., 2007; FAYER et al., 2008; BROOK et al., 2009). Both $C$. bovis and $C$. ryanae are much more prevalent in older, post-weaned dairy cattle (FELTUS et al., 2008; AYINMODE et al., 2010), although they have a low but widespread prevalence in pre-weaned calves (THOMPSON et al., 2007; SANTÍN et al., 2008) and other age groups (FAYER et al., 2006; FENG et al., 2007). C. andersoni has large oocysts and infects the abomasum of juvenile (1-2-year-old heifers) and adult cattle (>24 months old) persisting for years with a long oocyst shedding duration (KVÂC; VÍTOVEC, 2003; ROBINSON et al., 2006). Despite the abundant prevalence information for Cryptosporidium around the world, there is little information on the Cryptosporidium species and genotypes present in infected cattle in Brazil. This study was undertaken to determine the occurrence and characterize the species of Cryptosporidium present in dairy cattle in south-central São Paulo state, Brazil.

\section{Materials and Methods}

\section{Dairy farms and sample collection}

Feces were collected from dairy cattle located on ten farms in three counties (Pardinho, Botucatu and Itatinga) of south-central São Paulo state, Brazil (Table 1). All farms were visited between
February and August 2006. Dairy calves and cows were randomly selected for sampling. At each farm, 20 fecal specimens were collected from calves ( 2 weeks to 6 months of age) and cows (>24 months old). Two hundred cattle fecal samples were collected in total (100 from calves and 100 from cows). Feces were collected directly from the rectum of each animal into a plastic specimen cup that was immediately capped, labeled and placed on ice in an insulated container. Feces were transported to the laboratory of parasitic diseases, UNESP - Univ Estadual Paulista in Botucatu and processed on the same day of collection. Animals were generally grazed on pasture, housed in groups in large pens (either completely or partially covered by a roof) or housed in large free-stall barns.

\section{Light microscopy examination}

Cryptosporidium oocysts were identified microscopically in fecal smears after staining with a modified Ziehl-Neelsen stain (MARTINEZ; BELDA NETO, 2001).

\section{Antigen-EIA}

The CRYPTOSPORIDIUM TEST ${ }^{\circledR}$ antigen EIA kit (Techlab, USA) was used to demonstrate the presence of Cryptosporidium oocysts antigen in $10 \%$ formalin preserved samples. The diagnostic kit procedure was followed and the results were examined and interpreted according to the manufacturer's instructions. Results were read photometrically at $450 \mathrm{~nm}$. A sample was considered positive when the O.D. was $\geq 0.150$.

\section{PCR analysis}

Fecal specimens frequently contain PCR inhibitors and a large number of cells from the host (e.g., intestinal cells, blood cells). The adequacy of DNA isolation and purification was assessed for each isolate by first performing PCR amplification with specific primers sets targeting the mitochondrial DNA from bovine cells, as previously described (MARTELLINI et al., 2005). Mitochondrial

Table 1. City, farm designation, number of samples examined at each farm, number of positives, and prevalence of Cryptosporidium species/genotypes from 200 dairy cattle on 10 farms in the region of the counties of Pardinho, Botucatu and Itatinga, São Paulo state, Brazil.

\begin{tabular}{|c|c|c|c|c|c|c|}
\hline \multirow{2}{*}{ City } & \multirow{2}{*}{ Farm } & \multirow{2}{*}{$\mathrm{N}^{\circ}$ samples } & \multirow{2}{*}{$\mathrm{N}^{\circ}$ positives } & \multicolumn{3}{|c|}{ Species/Genotype } \\
\hline & & & & C. andersoni & C. bovis & C. parvum \\
\hline Pardinho & PAR 1 & 20 & $1(5)$ & 0 & $1(100)$ & 0 \\
\hline Pardinho & PAR 2 & 20 & $2(10)$ & 0 & $2(100)$ & 0 \\
\hline Botucatu & BTU 1 & 20 & $4^{*}(20)$ & $3(100)$ & 0 & 0 \\
\hline Botucatu & BTU 2 & 20 & $1(5)$ & $1(100)$ & 0 & 0 \\
\hline Botucatu & BTU 3 & 20 & $9(45)$ & $9(100)$ & 0 & 0 \\
\hline Botucatu & BTU 4 & 20 & $1(5)$ & $1(100)$ & 0 & 0 \\
\hline Botucatu & BTU 5 & 20 & $1(5)$ & $1(100)$ & 0 & 0 \\
\hline Itatinga & ITA 8 & 20 & $2(5)$ & $1(50)$ & 0 & $1(50)$ \\
\hline Itatinga & ITA 9 & 20 & $7(35)$ & $7(100)$ & 0 & 0 \\
\hline Itatinga & ITA 10 & 20 & $0(0)$ & 0 & 0 & 0 \\
\hline Total & 10 & 200 & $28(14)$ & $23(85.1)$ & $3(11.1)$ & $1(3.7)$ \\
\hline
\end{tabular}

The values in parentheses are percentages. ${ }^{*}$ An isolate from one calf could not be typed by RFLP analysis or sequencing. The total species/genotype percentages are based on the total of 27 positive samples submitted to genetic characterization. 
DNA gene targets were chosen for this assay because individual host cells contain numerous copies of mitochondrial DNA. The successful of amplification of this target demonstrates the absence of inhibitors in a DNA sample originating from feces.

\section{Isolation of $D N A$}

The QIAamp ${ }^{\circledR}$ DNA Stool Mini Test Kit (Qiagen, Germany) was used according to the manufacturer's instructions with a slightly modified protocol. The modifications include four cycles of freezing in liquid nitrogen for 5 minutes and boiling for 5 minutes to disrupt the oocyst cell walls to release DNA. The DNA was eluted from the silica column by applying $100 \mu \mathrm{L}$ AE-buffer and centrifugation at 16,000 $\mathrm{rcf}$ for 1 minute (to increase the quantity of recovered DNA). DNA was stored at $-20{ }^{\circ} \mathrm{C}$ until it was used for PCR assays

\section{SSU-rRNA gene PCR}

Cryptosporidium species and genotypes were identified using nested PCR-based protocol. The secondary PCR product from the small subunit (SSU) rRNA gene (with a size ranging from 826 to 864 bp depending on the isolate) was amplified by a nested PCR as previously described (XIAO et al., 2001).

\section{GP60 gene PCR}

A fragment of the $60 \mathrm{kDa}$ glycoprotein (GP60) gene was amplified by nested-PCR (PENG et al., 2003; GLABERMAN et al., 2002) using primers 5'-ATAGTCTCCGCTGTATTC-3' and 5'-GCAGAGGAACCAGCATC-3' (primary PCR) and 5'-TCCGCTGTATTCTCAGCC-3' and 5'-GAGATATATCTTGGTGCG-3' (secondary PCR). These primers were designed based on sequences conserved among all known C. parvum GP60 alleles.

\section{SSU-rRNA PCR-RFLP analysis}

PCR-RFLP analysis of the SSU-rRNA gene secondary PCR products was performed using $S_{s p} \mathrm{I}, V_{s p} \mathrm{I}, D d e \mathrm{I}$ and $M b o \mathrm{II}$ in order to differentiate Cryptosporidium species and genotypes (XIAO et al., 2001; FENG et al., 2007; PLUTZER; KARANIS, 2007). The master mix used for restriction digestion contained $2 \mu \mathrm{L}$ of reaction buffer, 5 units of each enzyme, endonuclease and nuclease-free water according to the manufacturer's instructions (Fermentas, USA). Restriction digestion was carried out at $37{ }^{\circ} \mathrm{C}$, overnight. Species/genotypes assignments were made by comparing the RFLP profiles to known profiles reported in the literature.

\section{SSU-rRNA gene and GP6O DNA sequencing analysis}

Selected PCR products for the SSU-rRNA and GP60 genes were sequenced in both directions with the forward and reverse primers used in the secondary PCRs. Sequencing was performed using a BigDye ${ }^{\circledR}$ Terminator v3.1 Cycle Sequencing Kit (Applied Biosystems, USA) and an ABI 3500 Genetic Analyzer ${ }^{\circledR}$ (Applied Biosystems, USA). The quality of the generated electropherograms was analyzed using ABI Sequencing Analysis ${ }^{\circledR}$ v5.3 software. The accuracy of the data was confirmed by bidirectional sequencing with the forward and reverse primers used in the secondary PCR. Sequence electropherograms from each strand were aligned and inspected using MEGA v.5 software (TAMURA et al., 2007). The nucleotide sequences of the SSU-rRNA and GP60 genes reported in this paper were aligned using Clustal W. The sequences obtained were compared against a database (GenBank at www. ncbi.nlm.nih.gov/BLAST) using BLAST software to determine the species and genotype of Cryptosporidium. Phylogenetic and molecular evolutionary analyses were performed with MEGA v. 5 and phylogenetic inference was done using the neighbor-joining (NJ) method. Genetic distance was calculated with the Kimura 2-parameter model.

\section{Cryptosporidium parvum subtype identification using the GP60 gene}

Cryptosporidium parvum subtypes were determined by sequence analysis of the GP60 gene and named using the protocol previously described (SULAIMAN et al., 2005). This nomenclature is based on the number of TCA (designated by the letter A), TCG (designated by the letter G) and ACATCA (designated by the letter $\mathrm{R}$ ) repeats in the microsatellite region. For example, a sequence with 15 TCA, 2 TCG and 2 ACATCA repeats was assigned A15G2R2 (SULAIMAN et al., 2005).

\section{Nucleotide sequence accession numbers}

The SSU-rRNA gene nucleotide sequences were deposited in GenBank under accession numbers JF937701 to JF937708 for $C$. andersoni isolates, JF957617 and JF957618 for $C$. bovis isolates. The $C$. parvum SSU-rRNA and GP60 gene nucleotide sequences were deposited in GenBank under accession numbers JN120853 and JF937700, respectively.

\section{Data analysis}

The occurrence rate of Cryptosporidium spp. throughout the study was calculated as the number of infected individuals divided by the number of individual's sampled $\times 100$. Agreements between diagnostic methods and the presence or absence of diarrhea in the populations infected or not infected with Cryptosporidium spp. were compared using the Kappa test. The farm occurrence was calculated as the number of farms with at least one positive sample compared with the total number of farms in the study.

\section{Results}

The occurrence of Cryptosporidium spp. infection in our study was $14 \%(28 / 200)$. Data relating to the number of calves examined at each farm location, the number of positive specimens at each 
location and the species or genotype of Cryptosporidium identified by PCR-RFLP and/or sequencing at the SSU-rRNA and GP60 genes are shown in Table 1.

\section{Detection of Cryptosporidium by microscopy, ELISA and PCR}

All 200 fecal specimens were tested using three diagnostic methods: microscopy, ELISA and PCR. We identified Cryptosporidium oocysts microscopically in 17 fecal samples after staining with a modified Ziehl-Neelsen stain. The ELISA method was significantly less sensitive, detecting parasites in only two samples. The PCR method proved to be the most sensitive (kappa=0.024) and was able to detect Cryptosporidium DNA in 28 samples. All Cryptosporidium-positive specimens generated the expected SSU-rRNA gene products by nested PCR ( $\sim 830-860 \mathrm{bp})$. None of the samples that were positive by microscopy/ELISA were negative by PCR. All specimens produced the expected bovine mitochondrial PCR product, indicating that PCR inhibitors were not responsible for the negatives results.

\section{Farms and handling}

Cryptosporidium spp. was detected in animals from $90 \%$ of the farms sampled in this study $(9 / 10)$. The occurrence of Cryptosporidium spp. in samples of each farm varied from 5\% - $45 \%$. No clear association was found between the type of housing and prevalence of infection.

\section{Relationship between Cryptosporidium infection and age}

The level of occurrence in calves was 26\% (26/100), which was higher than the occurrence of $2 \%(2 / 100)$ in cows. In specimens collected from 0 to 2 month-old calves, the occurrence was $23.8 \%$ ( 5 of the 21 calves in this category). Of the specimens collected from 2 to 6 month-old calves, $26.5 \%$ (21 of the 79 calves in this category) were positive for Cryptosporidium spp. As a percentage value, the lowest level of infection was found in 0 to 30 day-old calves, with Cryptosporidium spp. found in 16.6\% (1/6) of samples in this category. Eight samples (36.3\%) collected from calves at approximately 90 to 120 days $(8 / 22)$ were positive for Cryptosporidium spp. In 150 to 180 day-old calves (average 6 months old) the occurrence was $60 \%(3 / 5)$.

\section{Presence of diarrhea in calves}

Diarrhea was observed in $17 \%(17 / 100)$ of calves at the time of sampling. Cryptosporidium spp. was detected in 23.5\% (4/17) of diarrheic samples and in 26.5\% (22/83) of non-diarrheic samples; therefore diarrhea was not found to be statistically associated with infection (kappa=0.025) and had no specific correlation with any Cryptosporidium species.

\section{Species and genotypes by PCR-RFLP}

Restriction analysis produced a banding pattern diagnostic of $C$. andersoni for 23 (85.1\%) PCR products. Of the remaining samples, $C$. bovis was identified in three $(11.1 \%)$ and $C$. parvum in one $(3.7 \%)$. The isolate from one calf could not be typed by RFLP analysis or sequencing.

\section{Species and genotypes on farms}

The non-zoonotic $C$. andersoni was present in samples from seven of the 10 farms examined and was particularly prevalent on farms BTU-3 and ITA-9, with high numbers of calves infected. The infection rates with $C$. andersoni on each farm varied from 0 to $45 \%$. This species was responsible for $100 \%$ of the infected animals from six farms. Cryptosporidium bovis was the only Cryptosporidium species identified in samples from two farms in Pardinho. Cryptosporidium parvum was identified in specimens from only one farm.

\section{Relationship between Cryptosporidium species/geno- types and age}

Cryptosporidium andersoni was found in $100 \%$ of positive specimens from calves at 1, 5 and 6 months of age and in $100 \%$ of positive specimens from adult cattle. The species $C$. parvum was found in only one calf, which was 3 months of age. In calves 4 months of age or older, only C. bovis and C. andersoni were found. For 0 to 6 month-old calves, $C$. andersoni was the most prevalent species. C. parvum was not identified in specimens from 0 to 2 month-old calves. Cryptosporidium bovis was identified in $4.7 \%$ (1/21) of specimens from 0 to 2 month-old calves and in $2.5 \%$ (2/79) of specimens from 0 to 6 month-old calves. The percentage of each identified species and genotype of Cryptosporidium relative to the age of the animal is shown in Figure 1.

\section{Sequencing analysis of DNA sequences}

DNA sequencing of selected PCR products confirmed the results of the RFLP analysis. Partial sequences of the SSU-rRNA and GP60 genes were compared with Cryptosporidium sequence data obtained from GenBank. The SSU-rRNA sequences of $C$. bovis, C. parvum, and $C$. andersoni were identical to those previously reported for these species (FAYER et al., 2005; THOMAZ et al., 2007; SEVÁ et al., 2010). The sample that tested positive for the $C$. parvum genotype by SSU-rRNA PCR was subgenotyped by sequence analysis of the GP60 gene. The GP60 nucleotide sequences of the C. parvum isolate (BRAcalf72) revealed $100 \%$ identity with $C$. parvum subtype IIaA15G2R1, GenBank accession number EU549719 (QUILEZ et al., 2008).

\section{Discussion}

In the current cross-sectional study, Cryptosporidium spp. was identified in $14 \%(28 / 200)$ of animal tested by analysis of 


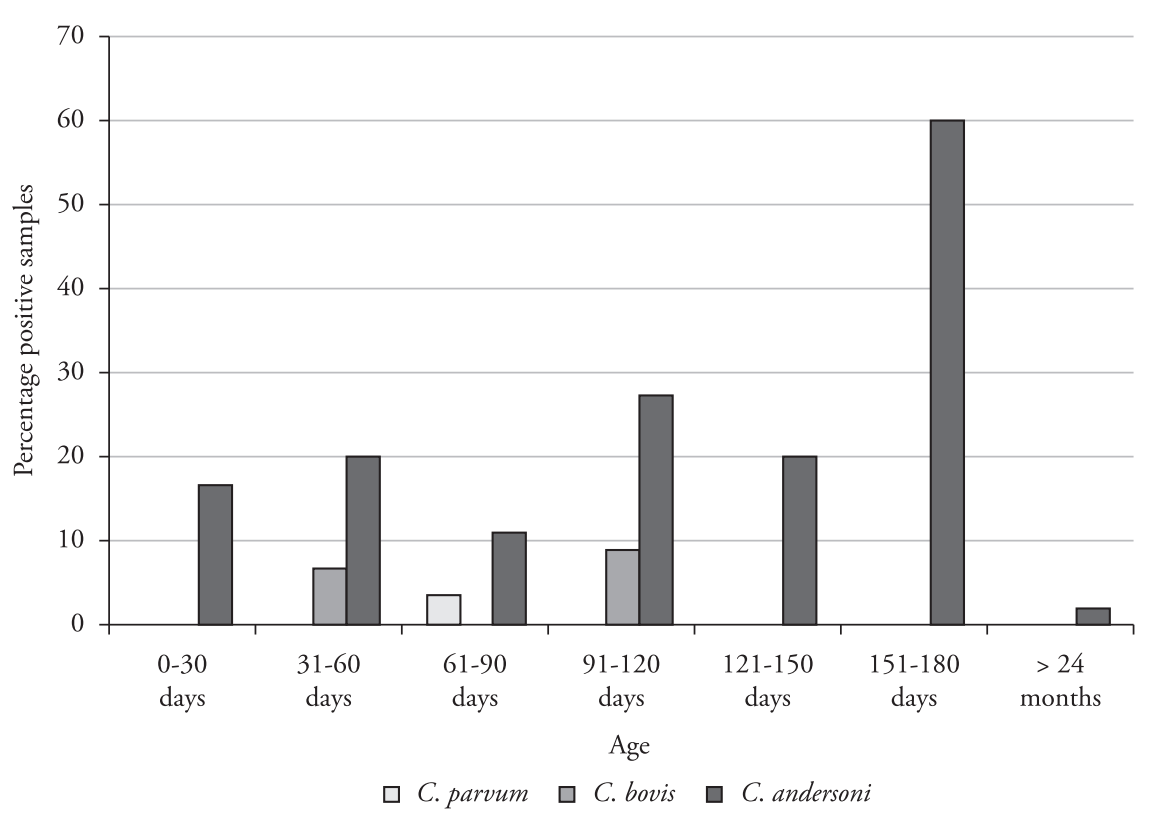

Figure 1. Relationship between age and occurrence of Cryptosporidium spp. in dairy cattle as determined by microscopy, ELISA and PCR. Data are based on specimens from 10 farms in south-central São Paulo state, Brazil.

a single fecal sample using microscopy, ELISA and PCR. Our results, as well as those of previous studies (MORGAN et al., 1998), indicate that the detection of Cryptosporidium oocysts in fecal smears by microscopy is less sensitive than the detection of DNA by PCR. In longitudinal studies, Cryptosporidium spp. has been found to be highly prevalent in dairy cattle (SANTÍN et al., 2008). In the present study, the occurrence of Cryptosporidium spp. in calves $(26 \%)$ was significantly higher than in cows $(2 \%)$. In epidemiological surveys in USA, Hungary, Germany, Ireland, Iran and Spain, the average prevalence of Cryptosporidium spp. in young calves ranged from $18.8 \%$ to $57.8 \%$ (SANTÍN et al., 2004; THOMPSON et al., 2007; BROGLIA et al., 2008; QUILEZ et al., 2008; KESHAVARZ et al., 2009) and the prevalence in adult cattle in Spain, Portugal and the USA ranged from $4.5 \%$ to 8.4\% (FAYER et al., 2006; CASTRO-HERMIDA et al., 2007; MENDONÇA et al., 2007).

\section{Prevalence of species and genotypes}

Previous studies aiming to genetically characterize Cryptosporidium spp. in cattle in Brazil have revealed the presence of C. parvum (HUBER et al., 2007; THOMAZ et al., 2007; MEIRELES et al., 2011), C. bovis (THOMAZ et al., 2007; MEIRELES et al., 2011), C. ryanae (MEIRELES et al., 2011) and C. andersoni (SEVÁ et al., 2010; MEIRELES et al., 2011) in isolates originating from animals in São Paulo and Rio de Janeiro state. In the majority of studies worldwide, $C$. parvum has been found to be most prevalent and widely distributed species in neonatal and pre-weaned dairy cattle (PENG et al., 2003; SANTÍN et al., 2004; HAMNES et al., 2006; TROTZ-WILLIAMS et al., 2006; COKLIN et al., 2007; GEURDEN et al., 2007; PLUTZER; KARANIS, 2007; THOMPSON et al., 2007). In the present study we found a very low prevalence of $C$. parvum in young calves from farms in the south-central region of São Paulo state. This low level of infection may be a consequence of the small number of fecal specimens collected from calves in each age category. C. bovis was identified in a small number of fecal samples from calves in the present study. This species has been found to be present at low levels in cattle of all age groups in the USA, Europe, Asia and Africa (FAYER et al., 2005; SANTÍN et al., 2004; FENG et al., 2007; THOMPSON et al., 2007; AYINMODE et al., 2010; WANG et al., 2011) and it is now clear that this species is also present at low levels in dairy cattle in Brazil, as reported in previous Brazilian surveys (THOMAZ et al., 2007; MEIRELES et al., 2011). C. andersoni has previously been identified in fecal samples from dairy cattle in Brazil (THOMAZ et al., 2007; MEIRELES et al., 2011) and worldwide (KVÁC; VÍTOVEC, 2003; FAYER et al., 2005; ROBINSON et al., 2006). This animal-specific Cryptosporidium species predominates in older calves, heifers and adult cattle (SANTÍN et al., 2004; FAYER et al., 2006; ROBINSON et al., 2006). However, in a study of dairy herds in São Paulo State (SEVÁ et al., 2010) a high frequency of $C$. andersoni in 0-6 month-old calves was found; a result that is markedly different from frequencies reported in others locations where $C$. parvum predominates. Our data support these findings and indicate that calves of all ages are susceptible to infection with $C$. andersoni; thus, this species is not specifically associated with adult cattle.

\section{Cryptosporidium parvum subtypes}

The $C$. parvum subtype IIaA15G2R1 was detected in the present study. This subtype is commonly found in both calves and human worldwide (FELTUS et al., 2006; THOMPSON et al., 2007; WIELINGA et al., 2008) and has been shown to be the most prevalent $C$. parvum subtype in calves in some 
herds in North America, Europe and Asia (ALVES et al., 2006; TROTZ-WILLIAMS et al., 2006; FENG et al., 2007; BROGLIA et al., 2008; QUILEZ et al., 2008; SANTÍN et al., 2008; BROOK et al., 2009). In Brazil, this subtype is widely distributed in calves in northwestern São Paulo state (MEIRELES et al., 2011).

\section{Zoonosis}

Our findings demonstrate that pre-weaned calves are not an important source of zoonotic cryptosporidiosis for humans in this region. However, additional studies in other regions of Brazil will be required to fully evaluate the prevalence of zoonotic species of Cryptosporidium in dairy calves and to determine the public health impact of these infections. Although $C$. andersoni appears to be the most prevalent species in cattle in this region, the presence of C. parvum (a zoonotic species common in humans) is of potential public health significance. Nevertheless, as observed in previous studies (FAYER et al., 2006; FENG et al., 2007), adult dairy cattle are a relatively low-risk source of infection for humans, because they usually harbor host-specific Cryptosporidium species.

\section{Conclusions}

The present study demonstrated that Cryptosporidium spp. is prevalent and widespread in dairy cattle farms in south-central Sáo Paulo state, Brazil. However, our results may reflect regional variation; clearly, additional data are needed on Cryptosporidium species and genotypes in cattle from others dairy farms in Brazil. Cattle in the studied region are primarily parasitized by $C$. andersoni, a species restricted to ruminants host and not found in humans. In conclusion, our results provide useful information about the distribution of Cryptosporidium species and genotypes in dairy cattle populations and contribute to our knowledge of the epidemiology of cryptosporidiosis in Brazil and throughout the world.

\section{Acknowledgments}

This study was supported by the Fundação de Amparo a Pesquisa do Estado de Sáo Paulo (FAPESP) - grant number 05/52175-2.

\section{References}

Alves M, Xiao L, Antunes F, Matos O. Distribution of Cryptosporidium subtypes in humans and domestic and wild ruminants in Portugal. Parasitol Res 2006; 99(3): 287-292. PMid:16552512. http://dx.doi. org/10.1007/s00436-006-0164-5

Ayinmode AB, Olakunle FB, Xiao L. Molecular characterization of Cryptosporidium spp. in native calves in Nigeria. Parasitol Res 2010; 107(4):1019-1021. PMid:20644959. http://dx.doi. org/10.1007/s00436-010-1972-1

Broglia A, Reckinger S, Cacció SM, Nöckler K. Distribution of Cryptosporidium parvum subtypes in calves in Germany. Vet Parasitol 2008; 154(1-2): 8-13. PMid:18394808. http://dx.doi. org/10.1016/j.vetpar.2008.02.029
Brook EJ, Anthony Hart C, French NP, Christley RM. Molecular epidemiology of Cryptosporidium subtypes in cattle in England. Vet J2009; 179(3): 378-382. PMid:18083583. http://dx.doi.org/10.1016/j. tvjl.2007.10.023

Castro-Hermida JA, Almeida A, González-Warleta M, Correia da Costa JM, Rumbo-Lorenzo C, Mezo M. Occurrence of Cryptosporidium parvum and Giardia duodenalis in healthy adult domestic ruminants. Parasitol Res 2007; 101(5): 1443-1448. PMid:17569991. http://dx.doi. org/10.1007/s00436-007-0624-6

Coklin T, Farber J, Parrington L, Dixon B. Prevalence and molecular characterization of Giardia duodenalis and Cryptosporidium spp. in dairy cattle in Ontario, Canada. Vet Parasitol 2007; 150(4): 297-305. PMid:17964724. http://dx.doi.org/10.1016/j.vetpar.2007.09.014

Fayer R, Santín M, Xiao L. Cryptosporidium bovis n. sp. (Apicomplexa: Cryptosporidiidae) in cattle (Bos taurus). J Parasitol 2005; 91(3): 624-629. PMid:16108557. http://dx.doi.org/10.1645/GE-3435

Fayer R, Santín M, Trout JM, Greiner E. Prevalence of species and genotypes of Cryptosporidium found in 1-2-year-old dairy cattle in the eastern United States. Vet Parasitol 2006; 135(2): 105-112. PMid:16159697. http://dx.doi.org/10.1016/j.vetpar.2005.08.003

Fayer R, Santín M, Trout JM. Cryptosporidium ryanae n. sp. (Apicomplexa: Cryptosporidiidae) in cattle (Bos taurus). Vet Parasitol 2008; 156(3-4): 191-198. PMid:18583057. http://dx.doi. org/10.1016/j.vetpar.2008.05.024

Feltus DC, Giddings CW, Schneck BL, Monson T, Warshauer D, McEvoy JM. Evidence supporting zoonotic transmission of Cryptosporidium spp. in Wisconsin. J Clin Microbiol 2006; 44(12): 43034308. PMid:17005736 PMCid:1698413. http://dx.doi.org/10.1128/ JCM.01067-06

Feltus DC, Giddings CW, Khaitsa ML, McEvoy JM. High prevalence of Cryptosporidium bovis and the deer-like genotype in calves compared to mature cows in beef cow-calf operations. Vet Parasitol 2008; 151(2-4): 191-195. PMid:18063483. http://dx.doi. org/10.1016/j.vetpar.2007.10.012

Feng Y, Ortega Y, He G, Das P, Xu M, Zhang X, et al. Wide geographic distribution of Cryptosporidium bovis and the deer-like genotype in bovines. Vet Parasitol 2007; 144(1-2): 1-9. PMid:17097231. http:// dx.doi.org/10.1016/j.vetpar.2006.10.001

Geurden T, Berkvens D, Martens C, Casaert S, Vercruysse J, Claerebout E. Molecular epidemiology with subtype analysis of Cryptosporidium in calves in Belgium. Parasitology 2007; 134(14): 1981-1987. PMid:17761023. http://dx.doi.org/10.1017/S0031182007003460

Glaberman S, Moore JE, Lowery CJ, Chalmers RM, Sulaiman I, Elwin $\mathrm{K}$, et al. Three drinking-water-associated cryptosporidiosis outbreaks, Northern Ireland. Emerg Infec Dis 2002; 8(6): 631-633. PMid:12023922 PMCid:2738494. http://dx.doi.org/10.3201/eid0806.010368

Hamnes IS, Gjerde B, Robertson L. Prevalence of Giardia and Cryptosporidium in dairy calves in three areas of Norway. Vet Parasitol 2006; 140(3-4): 204-216. PMid:16647210. http://dx.doi. org/10.1016/j.vetpar.2006.03.024

Huber F, Da Silva S, Bomfim TC, Teixeira KR, Bello AR. Genotypic characterization and phylogenetic analysis of Cryptosporidium sp. from domestic animals in Brazil. Vet Parasitol 2007; 150(1-2): 65-74. PMid:17905514. http://dx.doi.org/10.1016/j.vetpar.2007.08.018

Keshavarz A, Haghighi A, Athari A, Kazemi B, Abadi A, Mojarad EN. Prevalence and molecular characterization of bovine Cryptosporidium 
in Qazvin province, Iran. Vet Parasitol 2009; 160(3-4): 316-318. PMid:19091477. http://dx.doi.org/10.1016/j.vetpar.2008.11.008

Kvác M, Vítovec J. Prevalence and pathogenicity of Cryptosporidium andersoni in one herd of beef cattle. J Vet Med B Infect Dis Vet Public Health 2003; 50(9): 451-457. PMid:14633200. http://dx.doi. org/10.1046/j.0931-1793.2003.00701.x

Martellini A, Payment P, Villemur R. Use of eukaryotic mitochondrial DNA to differentiate human, bovine, porcine and ovine sources in fecally contaminated surface water. Water Res 2005; 39(4): 541-548. PMid:15707626. http://dx.doi.org/10.1016/j.watres.2004.11.012

Martinez I, Belda Neto FM. Contribution to the laboratory diagnosis of human cryptosporidiosis. Rev Inst Med Trop Sao Paulo 2001; 43(2): 79-82. PMid:11340480. http://dx.doi.org/10.1590/ S0036-46652001000200005

Meireles MV, De Oliveira FP, Teixeira WF, Coelho WM, Mendes LC. Molecular characterization of Cryptosporidium spp. in dairy calves from the state of São Paulo, Brazil. Parasitol Res 2011; 109(3): 949-951. PMid:21472404. http://dx.doi.org/10.1007/s00436-011-2336-1

Mendonça C, Almeida A, Castro A, De Lurdes Delgado M, Soares S, Da Costa JM, et al. Molecular characterization of Cryptosporidium and Giardia isolates from cattle from Portugal. Vet Parasitol 2007; 147(1-2): 47-50. PMid:17451881. http://dx.doi.org/10.1016/j.vetpar.2007.03.019

Morgan UM, Pallant L, Dwyer BW, Forbes DA, Rich G, Thompson RC. Comparison of PCR and microscopy for detection of Cryptosporidium parvum in Human Fecal Specimens: Clinical Trial. $J$ Clin Microbiol 1998; 36(4): 995-998. PMid:9542924 PMCid:104676.

Olson ME, O’Handley RM, Ralston BJ, McAllister TA, Thompson RC. Update on Cryptosporidium and Giardia infections in cattle. Trends Parasitol 2004; 20(4): 185-191. PMid:15099558. http://dx.doi. org/10.1016/j.pt.2004.01.015

Peng MM, Wilson ML, Holland RE, Meshnick SR, Lal AA, Xiao L. Genetic diversity of Cryptosporidium spp. in cattle in Michigan: implications for understanding the transmission dynamics. Parasitol Res 2003; 90(3): 175-180. PMid:12783304.

Plutzer J, Karanis P. Genotype and subtype analyses of Cryptosporidium isolates from cattle in Hungary. Vet Parasitol 2007; 146(3-4): 357-362. PMid:17391853. http://dx.doi.org/10.1016/j.vetpar.2007.02.030

Quilez J, Torres E, Chalmers RM, Robinson G, Del Cacho E, Sanchez-Acedo C. Cryptosporidium species and subtype analysis from dairy calves in Spain. Parasitology 2008; 135(14): 1613-1620. PMid:18980704. http://dx.doi.org/10.1017/S0031182008005088

Robinson G, Thomas AL, Daniel RG, Hadfield SJ, Elwin K, Chalmers RM. Sample prevalence and molecular characterisation of Cryptosporidium andersoni within a dairy herd in the United Kingdom. Vet Parasitol 2006; 142(1-2): 163-167. PMid:16908101. http://dx.doi. org/10.1016/j.vetpar.2006.06.031
Santín M, Trout JM, Xiao L, Zhou L, Greiner E, Fayer R. Prevalence and age-related variation of Cryptosporidium species and genotypes in dairy calves. Vet Parasitol 2004; 122(2): 103-117. PMid:15177715. http:// dx.doi.org/10.1016/j.vetpar.2004.03.020

Santín M, Trout JM, Fayer R. A longitudinal study of cryptosporidiosis in dairy cattle from birth to 2 years of age. Vet Parasitol 2008; 155(1-2): 15-23. PMid:18565677. http://dx.doi.org/10.1016/j.vetpar.2008.04.018

Sevá AP, Funada MR, Souza SO, Nava A, Richtzenhain LJ, Soares RM. Occurrence and molecular characterization of Cryptosporidium spp. isolated from domestic animals in a rural area surrounding Atlantic dry forest fragments in Teodoro Sampaio municipality, State of São Paulo, Brazil. Rev Bras Parasitol Vet 2010; 19(4): 249-253. PMid:21184703. http://dx.doi.org/10.1590/S1984-29612010000400011

Sulaiman IM, Hira PR, Zhou L, Al-Ali FM, Al-Shelahi FA, Shweiki HM, et al. Unique endemicity of cryptosporidiosis in children in Kuwait. J Clin Microbiol 2005; 43(6): 2805-2809. PMid:15956401 PMCid:1151898. http://dx.doi.org/10.1128/ JCM.43.6.2805-2809.2005

Tamura K, Dudley J, Nei M, Kumar S. MEGA4: Molecular Evolutionary Genetics Analysis (MEGA) software version 4.0. Mol Biol Evol 2007; 24(8): 1596-1599. PMid:17488738. http://dx.doi. org $/ 10.1093 / \mathrm{molbev} / \mathrm{msm} 092$

Thomaz A, Meireles MV, Soares RM, Pena HF, Gennari SM. Molecular identification of Cryptosporidium spp. from fecal samples of felines, canines and bovines in the state of São Paulo, Brazil. Vet Parasitol 2007; 150(4): 291-296. PMid:17996373. http://dx.doi. org/10.1016/j.vetpar.2007.09.023

Thompson HP, Dooley JS, Kenny J, McCoy M, Lowery CJ, Moore JE, et al. Genotypes and subtypes of Cryptosporidium spp. in neonatal calves in Northern Ireland. Parasitol Res 2007; 100(3): 619-624. PMid:17031699. http://dx.doi.org/10.1007/s00436-006-0305-x

Trotz-Williams LA, Martin DS, Gatei W, Cama V, Peregrine AS, Martin SW, et al. Genotype and subtype analyses of Cryptosporidium isolates from dairy calves and humans in Ontario. Parasitol Res 2006; 99(4): 346-352. PMid:16565813. http://dx.doi.org/10.1007/s00436-006-0157-4

Xiao L, Singh A, Limor J, Graczyk TK, Gradus S, Lal A. Molecular characterization of Cryptosporidium oocysts in samples of raw surface water and wastewater. Appl Environ Microbiol 2001; 67(3): 1097-1101. PMid:11229897 PMCid:92700. http://dx.doi.org/10.1128/ AEM.67.3.1097-1101.2001

Wang R, Wang H, Sun Y, Zhang L, Jian F, Qi M, et al. Characteristics of Cryptosporidium transmission in pre-weaned dairy cattle in Henan, China. J Clin Microbiol 2011; 49(3): 1077-1082. PMid:21177898 PMCid:3067708. http://dx.doi.org/10.1128/JCM.02194-10

Wielinga PR, De Vries A, Van Der Goot TH, Mank T, Mars MH, Kortbeek LM, et al. Molecular epidemiology of Cryptosporidium in humans and cattle in The Netherlands. Int J Parasitol 2008; 38(7): 809-817. PMid:18054936. http://dx.doi.org/10.1016/j.ijpara.2007.10.014 